\begin{tabular}{|c|c|c|c|c|}
\hline \multirow{2}{*}{ (N) } & \multicolumn{3}{|c|}{$\begin{array}{l}\text { PORT SAID ENGINEERING RESEARCH JOURNAL } \\
\text { Faculty of Engineering - Port Said University }\end{array}$} & \\
\hline & Volume. (20) $\quad$ No. 1 & March 2016 & pp. 71:77 & \\
\hline
\end{tabular}

\title{
Factors Leading to Cost Overrun Occurrence in Construction Projects
}

Mostafa Mohammed Abdel-Hafeez ${ }^{1}$, Sherif Sabry El-Attar ${ }^{2}$, and Walaa Ahmed Abdel-Hafez ${ }^{3}$

\begin{abstract}
Cost is the fundamental component for any construction project. While observations indicate that the cost overrun is a major phenomenon in construction industry worldwide. Hence, there are several factors responsible for cost overruns. So, a lot of studies have been conducted to investigate it. The aim of this paper is to identify the latest top major factors causing construction cost overrun construction projects in both of developed and developing countries (in particular) according to many variables during last three decades. through a comprehensive literature review, most common and frequently occurring causes of cost overrun worldwide and developing countries in particular were listed, factors were prioritized according to their occurrence, it is concluded that however cost overrun factors vary considerably across countries, the study of causing factors of cost overrun in construction projects will provide a reference for other projects that might be executed in similar circumstances and will also provide valuable information for international companies which intend to provide construction projects.
\end{abstract}

Keywords: Construction Projects, Factors, Planned Cost, Actual Cost, Cost Overrun.

\section{INTRODUCTION}

Cost is the fundamental component for any construction project. However, cost overrun is observed as one of the most frequently occurring issues in construction projects worldwide and need to be more studied to alleviate this issue in the future [1].

Cost overrun (CO) has become a norm, rather than an exception in the construction industry. So, it is normal to expect that the final cost of a project exceed the initial budget [2]. $C O$ was defined as situation where the amount of money used is greater than the estimated cost of project [3].

In addition, $C O$ in construction project is an indication of project failure so, the key to success is to realize and understand the challenges early in the planning process, to develop strategies to address them and to establish accurate and achievable expectations. Moreover, it provides the decision makers with early warning devices to reduce the cost overrun problems. So, understanding these factors allows for appropriate actions to mitigate factor impacts. Project participants can take action to curtail or control the effects of these identified cost escalation factors throughout the life of the project. Indeed, cost overrun occurs due to many factors that differ from one country to another.

Previous studies show that, the ranking of factors

${ }^{1}$ Professor at Department of Architectural Engineering and Urban Planning, Faculty of Engineering, Port Said University.

${ }^{2}$ Professor at Department of Architecture Engineering, Faculty of Engineering, Fayoum University.

${ }^{3}$ Master's Degree Holder of the Department of Architectural Engineering and Urban Planning, Faculty of Engineering, Port Said University. causing cost overrun is different from one country to another because of the different circumstances that surround construction industry. So, the main objective of this paper is to determine and discuss the most influencing factors in the cost of construction projects and causing cost overrun occurrence. This was fulfilled through literature review of different studies on this problem that aimed at:

- Identifying the latest factors that cause of cost overrun in construction projects.

- Classifying factors regarded to their related categories.

- Conducting a comparison among factors causing cost overrun in developed and developing countries.

\section{COST OVERRUN IN CONSTRUCTION INDUSTRY}

Cost is the common factor of any construction project. However, cost overrun is one of the most occurring risks construction projects and the most severe in developing countries, where these overruns sometimes exceed $100 \%$ of the estimated budget [1]. Construction cost which is out of control adds investment pressure, increases construction cost, affect investment decision-making. Hence, it is important to identify the factors that contribute to cost overrun to avoid and reduce the problems [4]. So, the increase in cost of project (cost overrun) can reduce the feasibility of the project [5]. 
Table1: The global experiments with cost overrun in construction projects [6]

\begin{tabular}{|l|l|c|c|}
\hline The project & $\begin{array}{l}\text { PC/ } \\
\text { million } \\
\text { dollar }\end{array}$ & $\begin{array}{l}\text { AC/ } \\
\text { million } \\
\text { dollar }\end{array}$ & CO \% \\
\hline $\begin{array}{l}\text { Suez Canal } \\
\text { (Egypt-1869) }\end{array}$ & 200 & 600 & 300 \\
\hline $\begin{array}{l}\text { Brooklyne Bridge } \\
\text { (USA-1883) }\end{array}$ & 15 & 30 & 100 \\
\hline $\begin{array}{l}\text { Sydny Opera house } \\
\text { (Australia-1973) }\end{array}$ & 7 & 102 & 1457 \\
\hline $\begin{array}{l}\text { The ryugyong Hotel } \\
\text { (North Korea-1992) }\end{array}$ & 230 & 750 & 326 \\
\hline $\begin{array}{l}\text { Scottish Parliament } \\
\text { Building (UK-2004) }\end{array}$ & 10 & 414 & 935 \\
\hline $\begin{array}{l}\text { Burj Al-khalifa } \\
\text { (UAE-2010) }\end{array}$ & 800 & 1500 & 187.5 \\
\hline
\end{tabular}

The problem of $\mathrm{CO}$ in construction projects is not confined to developing countries only but also in global projects as clarified in table1. Also, large construction projects have been plagued by cost and schedule overruns [6]. In general, if the increase's rate exceeds the $15 \%$ in project's cost; it will be considered as cost overrun. Hence, the normal range of cost overrun is between 0 and $15 \%$. [7].

\section{FACTORS LEADING TO COST OVERRUN IN CONSTRUCTION PROJECTS}

There are many factors causing of project cost deviation in other words, causes of variations between estimated cost or planned cost (PC) and actual cost (AC) of project which will be explained in details later. Hence, the researcher reviewed a lot of studies concern with the causing factors of cost overrun in construction projects. Many studies show that $90 \%$ of construction projects have underestimated costs and this percentage increases in the developing countries because of the lack of experience in the project management process. So, there are many factors can cause cost overrun that are different from one project to another and from one place to another. Cost overrun will be identified, its reasons will be clarified, and many of previous studies will be analyzed [8].

\subsection{PREVIOUS STUDIES RELATED TO STUDY'S SUBJECT}

There are a number of researches about factors leading to cost overrun occurrence in construction projects in several countries (developed and developing countries), as follow. However, it should be performed more such studies in developing countries, in particular Egypt to face the critical problem of cost overrun in construction field. Past researchers studied the factors affecting construction costs from various perspectives. However, different countries have different cost factors for consideration. After the literature review, the researcher extracted the following facts:

Whereas, Ekab, (2009) mentioned that poor review of drawings and Changes in design is the most influencing factor in cost overrun of construction projects in Iraq then, poor contracts management and fluctuation in material prices [9]. Besides, the viewpoint of Bageis and Fortune. (2009) and Alfouzan, (2013) that there are many factors lead to cost overrun in construction projects in KSA as Decision-making regarding tenders which depend on the size of contractor, contractor's classification status and type of main client, corruption in selling lands and government's poor role in monitoring materials prices [10][11]. Whereas, Zujo et al. (2010) the main only factor causes cost overrun in Bosnia and Herzegovina is the delay in project's handing over [12]. In addition, Ameh et al. (2010) extracted that the junior factors cause cost overrun in Nigeria are the economic stability, shortage of materials, government policies (laws and regulations), domination of construction industry by foreign firms and aids, project location and absence of construction cost data [13]. But, Singh et al. (2011) and Shanmuganathan and Baskar, (2015) mentioned that the junior factors cause cost overruns in India are uncompleted initial designs and poor contracts, ineffective construction management, poorly established cost control systems, poor project (site) management, poor cost control, additional work, Improper planning and changes or discrepancies which occur during the construction period [14][15].

Gajewska, and Ropel, (2011) stated that the delay in diction making, miscalculation, and not finding the right contractor are the most influencing factors of delay the construction projects which leading to cost overrun occurrence in Sweden [16]. In addition, Memon et al, (2011), Toh et al, (2012) and Abd-Karim et al, (2013) mentioned that client requirements on quality, poor design and delays in design, unrealistic contract duration and requirements imposed lack of experience, late delivery of materials and equipment, relationship between management and labor, fluctuation of prices of materials, cash flow and financial difficulties faced by contractors and shortages of materials are the most influencing factors in cost overrun in Malaysia [7][17] [18].

In addition, Mahamid et al. (2011) the junior factors cause cost overrun in Palestine are Materials price fluctuation, Insufficient duration for estimation, Lake of experience in contracts, Size of contract and Poor review of drawings [19], but, Bosenena, * (2011) saw that the only factor causes cost overrun in Jordan is The Delay (Increase in duration) [5]. Whereas, Arcila, (2012) stated that the most common cause of cost overrun in projects in UK are clients changing their mind during the course of the project, financial performance of the job contracts management, insufficiency in planning and design quality [2]. Whereas, Banaitiene and Banaitis, (2012) stated that 
lack of experience, design errors, scheduling errors and failure to comply with contractual quality requirements, and technology changes in Croitia [20]. In addition, Apolot et al, (2012) stated that the most influencing factors of cost overrun in Uganda are lack of project management during execution: insufficient and ineffective working, delays, changes in scope of work and location, law and order [21]. Besides, Doloi, (2013) clarified that the planning and scheduling deficiencies, Methods/techniques of construction, effective monitoring and feedback process, complexity of design and construction, improper control over site resource allocations and contractor's deficiencies in planning and scheduling at tender stage are the main causes of cost overrun of construction projects in Australia [22]. But, Siemiatycki, (2015) briefly mentioned that economic and political factors cause cost overrun in construction projects in Canada [23].

Finally, Shaqour, (2014); Khodeir and Hamdy, (2015) and Yakoub, (2016) mentioned that the junior factors cause cost overrun in Egypt are changes in project scope, material prices, Poor estimation of project cost, additional works at owner's request, donor policy in bidding to the lowest price, fluctuations in the cost of building materials, delay in project completion time, fraudulent practices, kickbacks, corruption and economic instability/ political insecurity [6] [24] [25].

\subsection{MUTUAL COST OVERRUN FACTORS BETWEEN DEVELOPED AND DEVELOPING COUNTRIES}

The factors causing cost overrun (CFFO) occurrence in construction projects between developed and developing countries, that comparison results in some mutual factors between developed and developing countries as poor estimation, poor planning, additional works, unqualified labor, design changes, delay in projects completion and environmental factors. As shown in the following figure:

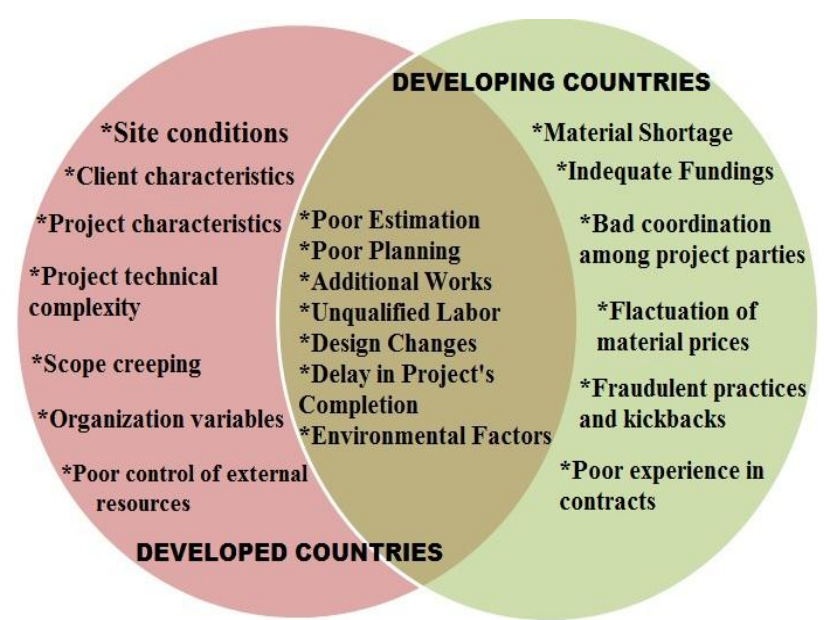

Figure 1: A comparison between developed and developing countries
This comparison indicated to some facts as construction projects in developing countries suffer from managerial, financial, contractual and project resource problems, so the decision makers should take those factors in consideration to avoid cost overrun occurrence.

\section{CLASSIFICATION OF COST OVERRUN FACTORS OF CONSTRUCTION PROJECTS}

The following structure of cost overrun factors is extracted from the previous studies analysis in both of developed and developing countries. Hence, it consists of six main groups of cost overrun factors as technical group, financial and economic group, political situation group, managerial group, project resources group and environmental factors group.

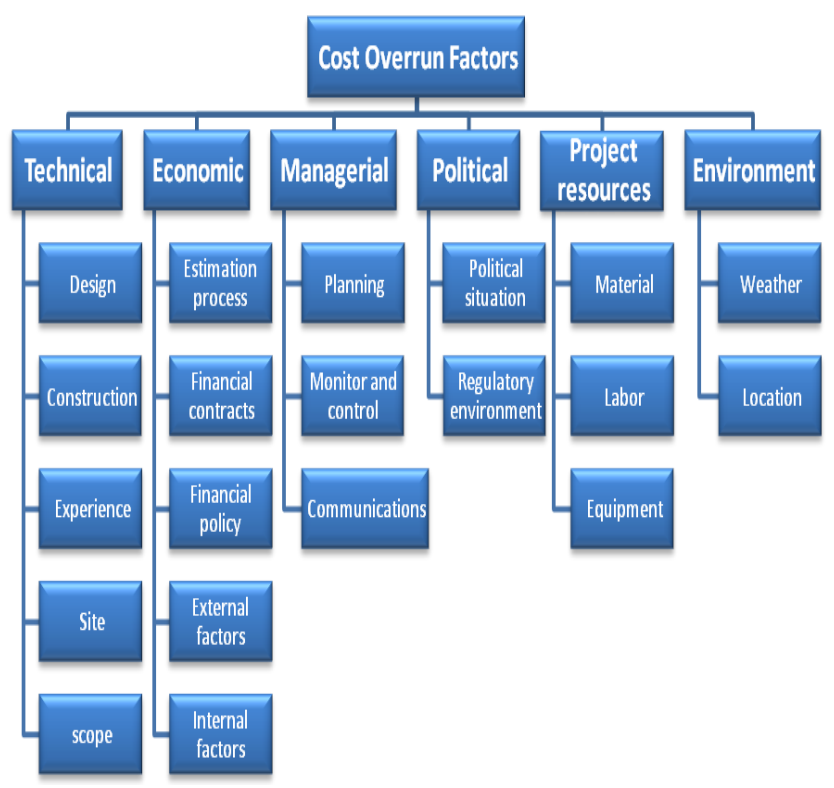

Figure 2: Factors causing cost overrun according to previous studies

Hence, each group has many categories according to the nature of included factors. Consequently, the researcher allocates the appropriate category for its factors in tables (2), (3), (4), (5), (6), and (7) as follow:

Table 2: The factors of technical group

\begin{tabular}{|l|l|}
\hline & $\begin{array}{l}\text { The related factors to this category are } \\
\text { Poor review of drawings and Changes in } \\
\text { design[2][6][7][9][14][15][17][18][19][20 } \\
{[22][24][25] .}\end{array}$ \\
\hline & $\begin{array}{l}\text { The related factors to this category are } \\
\text { Poor technical performances, changes or } \\
\text { discrepancies that may occur during the } \\
\text { construction period, technical complexity } \\
\text { of a project and Delay in a project's } \\
\text { handing over [5][7][12][16][17][18][20] } \\
\text { [21]. }\end{array}$ \\
\hline
\end{tabular}




\begin{tabular}{|c|c|}
\hline : & $\begin{array}{l}\text { The related factors to this category are } \\
\text { Decision-making in tendering processes, } \\
\text { Lack of experience and Delays between } \\
\text { design and procurement phases } \\
{[10][11][19][20][24][25] .}\end{array}$ \\
\hline 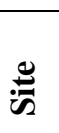 & $\begin{array}{l}\text { The related factors to this category } \\
\text { are Unforeseen site conditions and Poor } \\
\text { site organization [14][15]. }\end{array}$ \\
\hline ڤัँّ & $\begin{array}{l}\text { The related factors to this category are } \\
\text { Additional work at owner's request, } \\
\text { Changing orders and Poor scope definition } \\
{[2][16][21][24][25] \text {. }}\end{array}$ \\
\hline
\end{tabular}

Table 3: The factors of Economic and financial group

\begin{tabular}{|l|l|}
\hline & $\begin{array}{l}\text { The related factors to this category are } \\
\text { Donor policy in bidding to the lowest price, } \\
\text { Lake experience in contracts and Poor } \\
\text { contracts management } \\
{[2][6][9][14][15][19][20][24][25] .}\end{array}$ \\
\hline & $\begin{array}{l}\text { The related factors to this category are } \\
\text { Poor investment decisions, Inadequate } \\
\text { funding and Methods of financing and } \\
\text { payments for completed works } \\
\text { [2][6][24][25]. }\end{array}$ \\
\hline & $\begin{array}{l}\text { The related factors to this category are } \\
\text { Poor contractor management, } \\
\text { organizational variables, Project } \\
\text { characteristics and Client characteristics } \\
\text { [6][10][11][19][24][25]. }\end{array}$ \\
\hline \multirow{2}{*}{$\begin{array}{l}\text { The related factor to this category is } \\
\text { Fluctuation in money exchange rate, } \\
\text { domination of construction industry by } \\
\text { foreign firms and aids, government policies } \\
\text { (laws and regulations) and economic } \\
\text { instability [6][13][21][23][24][25]. }\end{array}$} \\
\hline
\end{tabular}

Table 4: The factors of political and regulation group

\begin{tabular}{|l|l|}
\hline The related factors to this category are \\
Unsupportive governmental policies and \\
Governmental control and regulations \\
[6][13][19][23][24][25].
\end{tabular}

Table 5: The factors of Management group

\begin{tabular}{|c|c|}
\hline 焉 & $\begin{array}{l}\text { The related factors to this category are } \\
\text { naccurate or poor estimation of Original } \\
\text { cost, Incorrect/inappropriate methods of } \\
\text { ost estimation and Estimating process risk } \\
6][16][19][24][25] \text {. }\end{array}$ \\
\hline : & $\begin{array}{l}\text { The related factors to this category are } \\
\text { nadequate project analysis, Improper planning } \\
\text { and scheduling and Poor planning } \\
2][6][7][14][15][16][17][18][19][20][21] \\
22][24][25] \text {. }\end{array}$ \\
\hline
\end{tabular}

\begin{tabular}{|c|c|}
\hline 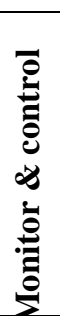 & $\begin{array}{l}\text { The related factors to this category are } \\
\text { Poor site management, Poor cost control, } \\
\text { Complexity of organizational structure of a } \\
\text { project, absence of construction cost } \\
\text { data and Fraudulent practices and } \\
\text { kickbacks }[6][7][11][13][17][18][19] \\
{[21][22] \text {. }}\end{array}$ \\
\hline 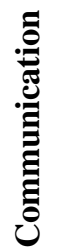 & $\begin{array}{l}\text { The related factors to this category are } \\
\text { Poor coordination among the project } \\
\text { participants and Lack of leadership } \\
\text { knowledge [21][24]. }\end{array}$ \\
\hline
\end{tabular}

Table 6: The factors of project resources group

\begin{tabular}{|c|l|}
\hline Category & Factors \\
\hline $\begin{array}{c}\text { The related factors to this category } \\
\text { are Lack of labor and Unqualified labor } \\
{[19][25] .}\end{array}$ \\
\hline & $\begin{array}{l}\text { The related factors to this category } \\
\text { are Fluctuations in the cost of building } \\
\text { materials, The shortage in construction } \\
\text { materials in markets and Materials } \\
\text { problem[6][9][10][11][13][14][15] } \\
{[19][24][25] .}\end{array}$ \\
\hline \multirow{2}{*}{$\begin{array}{l}\text { The related factors to this category } \\
\text { are - High cost of machineries and } \\
\text { Lack of equipment [7][17][18]. }\end{array}$} \\
\hline
\end{tabular}

Table 7: The factors of environment group

\begin{tabular}{|l|l|}
\hline & $\begin{array}{l}\text { The related factor to this category is } \\
\text { Poor field investigation [13][21]. }\end{array}$ \\
\hline & $\begin{array}{l}\text { The related factors to this category } \\
\text { are Unpredictable weather conditions } \\
\text { and Unsuitable climate to work } \\
{[14][22] .}\end{array}$ \\
\hline
\end{tabular}

\section{RESULTS AND DISCUSSION}

In fact, construction overrun is not unique to developing countries. It is a worldwide issue worsened by the global financial crisis; so, it is a major problem in construction industry development and a regular feature in construction industry. 


\section{Previous Studies in Developing Countries}

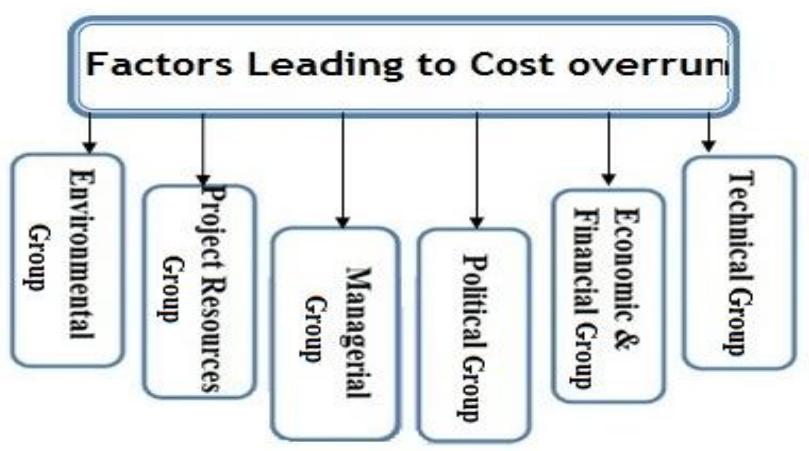

Figure 5: The groups of factors leading to cost overrun in construction projects

In addition, the main findings of the paper can be summarized as follows:

- The factors cause cost overrun in construction projects differ from one country to another because of the different circumstances that surround construction industry in each country.

-Most of the factors are related to financial issues. The most frequent factors in previous studies.

- Factors related to planning category are the main factors contribute to cost overrun in the projects of developing countries.

- Factors related to material category are the main factors contribute to cost overrun in the projects of developed countries.

-The scholars see that environmental factors are not serious problems, so the authors consider that they are not very important for cost overrun occurrence.

\section{Previous Studies Worldwide}
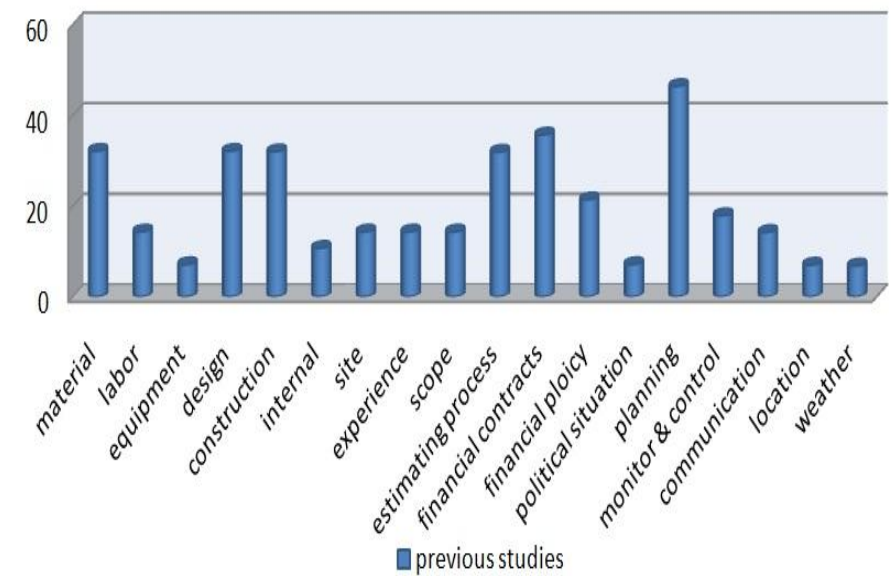

Figure 6: Analysis of previous studies worldwide

According to the previous studies' view, table 8 shows the top five (high-priority) categories of factors that affecting cost overrun in building construction projects. In a descending order they are: planning, financial contracts, estimating process, design and construction.
40

20

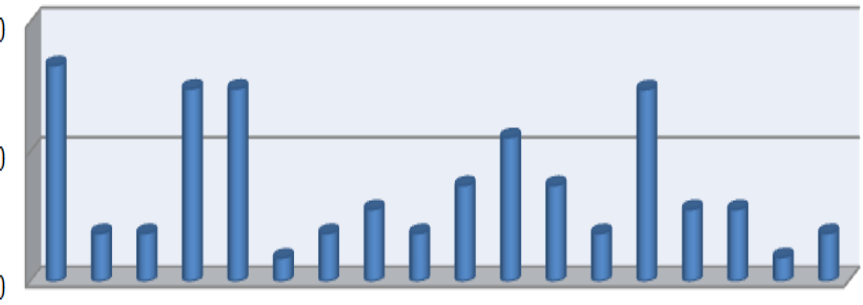

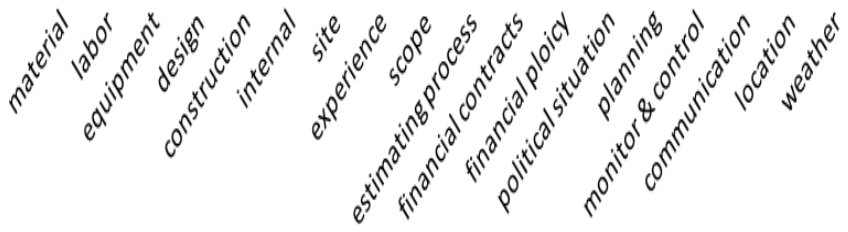

Dprevious studies

Figure 7: Analysis of previous studies in developing countries

Previous studies were conducted in the many developing countries as Ethiopia, Uganda, Ghana, Nigeria, Indonesia, Thai, India, Pakistan, Kuwait, Jordan and KSA. These studies result in some facts as, material, planning, design, construction and financial contracts are the top categories of influencing factors in cost overrun occurrence.

Table 8 shows the top five priority categories that affecting cost overrun in building construction projects globally and at the level of developing countries in a descending order, as a comparison between global and developing countries' previous studies according to the ranking of causing factors categories in cost overrun.

Table 8: A Comparison for ranking the categories of cost overrun factors

\begin{tabular}{|c|c|c|c|}
\hline Ranking & Worldwide & $\begin{array}{c}\text { Developing } \\
\text { countries }\end{array}$ & Egypt \\
\hline $\mathbf{1}$ & Planning & Material & Scope \\
\hline $\mathbf{2}$ & $\begin{array}{c}\text { Financial } \\
\text { contracts }\end{array}$ & Planning & $\begin{array}{c}\text { Estimation } \\
\text { process }\end{array}$ \\
\hline $\mathbf{3}$ & $\begin{array}{c}\text { Estimating } \\
\text { process }\end{array}$ & Design & $\begin{array}{c}\text { Political } \\
\text { situation }\end{array}$ \\
\hline $\mathbf{4}$ & Design & Construction & Planning \\
\hline $\mathbf{5}$ & Construction & $\begin{array}{c}\text { Financial } \\
\text { contracts }\end{array}$ & $\begin{array}{c}\text { External } \\
\text { factors }\end{array}$ \\
\hline
\end{tabular}

\section{CONCLUSION}

Cost overrun is considered an obvious indicator of project's failure, that a situation of a construction project in which budgetary estimate exceeds estimation, budget exceeds budgetary estimate, and settlement exceeds budget is a universal phenomenon. 


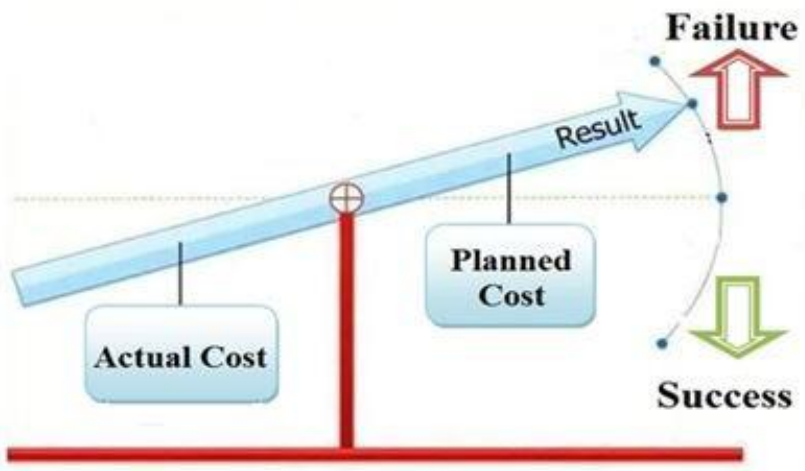

Figure 3: The impact of Cost overrun on Project Situation

1- The methodology used in this paper consisted of steps similar to ones used in most of the previous qualitative studies. This research is carried out in two stages. (literature review and analysis of findings). So, the researcher used the descriptive analytical approach depending on literature review and analysis of studies which deal with the factors affecting costs of construction projects.

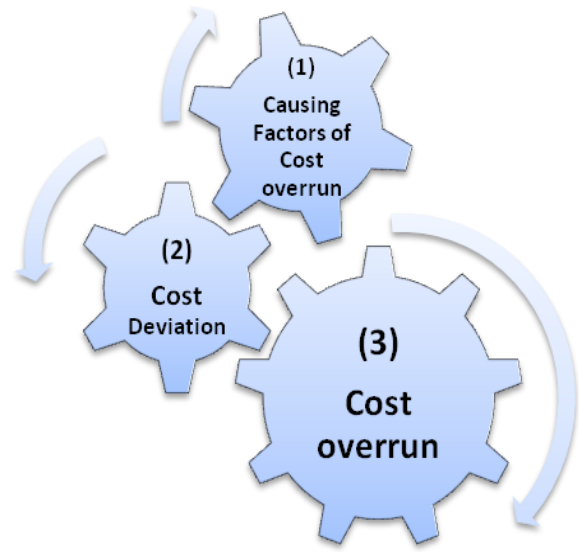

Figure 4: The dynamism of cost overrun occurrence in construction projects

2- The cost overrun factors lead to project cost growth have been documented through a large number of studies. So they were identified from literature survey worldwide. Consequently, these cost factors are grouped into six groups, these six main groups, namely: technical, economic \&financial, political \&regulation, management, project resources and environmental factors.

3- The groups contain about 20 categories of factor causing cost overrun in construction projects. Despite some differences in viewpoints held by each scholar, there are areas of agreement among them. All the groups felt that poor esimation of project costs, poor planning, additional works, unqualified labor, design changes, delay in project's completion and environmental factors are the major causes of cost overrun.

\section{RECOMMENDATIONS}

1. Construction companies should establish a data base of FCCO and use an effective tool to control these factors in their projects for improving the performance and increase the profits.

2. Avoid unnecessary additions to the project scope that don't add a value to the performance or functionality of the construction components or elements and focus on client's need.

3. The project's owners should depend on a scientific way in contractors' selection instead of the donor policy in bidding to the lowest price to guarantee executing the project without any financial stumbles and delay.

4. Developing the construction contracts by imposition more fines and restrictions in order to control project parties' claims and disputes related to cost overrun amount that is expected to occur in future.

5. Using modern techniques in cost estimation and project planning to improve their accuracy as cost management, risk management and value engineering.

6. Expanding the number of material choices on a given project and considering allowing alternate materials by providing flexibility in specifications or by allowing other material options to the contractors.

7. Adoption of tools and techniques i.e.: value Management, lean thinking, and total quality management to face the problem of Delay in project completion time.

8. Monitoring the design changes to avoid reassessment implementation cancelling unless the opportunity outweighs the threat. It is preferred to take more time during design to get it right in the first place.

9. Accept cost saving proposals from contractors during bidding and construction. Hence, the contractors may be more motivated to submit such proposals when potential cost savings are shared and it should be negotiated in contracts or meetings of stakeholders.

\section{NOMENCLATURE}

$\begin{array}{ll}\text { CO } & \text { Cost overrun } \\ \text { FCCO } & \text { Factors causing cost overrun } \\ \text { PC } & \text { Planned Cost } \\ \text { AC } & \text { Actual Cost }\end{array}$

\section{REFERENCES}

[1] Memon, A., Rahman, I. and Abdullah, M. 2010: Factors Affecting Construction Cost in Mara Large Construction Project, International Journal of Sustainable Construction Engineering \& Technology.

[2] Arcila, S. 2012: Avoiding cost overrun in construction projects in UK, master thesis, The University of Warwick, UK.

[3] Singh, R. 2009: Delays and Cost Overruns in Infrastructure Projects: An Enquiry into Extents, Causes and Remedies, Centre for Development Economics. It's 
retrieved from http://www.cdedse.org/pdf/work181.pdf. Access: 29-8-2013.

[4] Ali, A. and Kamaruzzaman, S. 2010: Cost performance for building construction projects in klang valley, Journal of Building Performance, Volume 1 Issue 12010

[5] بوسنينة، محمد على. 2011: در اسة التأخير ات فى المشاريع الإنشائية

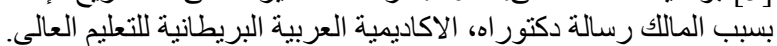

[6] Yakoub, W. 2016: New Approach to control the cost of construction projects in Egypt. M.Sc. Thesis, Faculty of Engineering, Port Said, Egypt.

[7] Abd-Karim, A., Memon, A. and Abdul-Rahman, I. 2013: Relationship between Factors of Construction Resources Affecting Project Cost, modern applied science. vol 7 . no.1.

[8] Ammar, M.; Elsamadony, A. and Rabie, A. 2009: Risk Allocation and Response in the Egyptian Barrage Projects, Thirteenth International Conference on Structural and Geotechnical Engineering, 13th ICSGE 27-29, Cairo, Egypt.

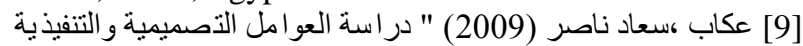

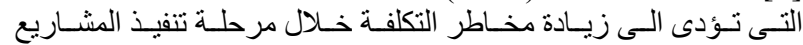

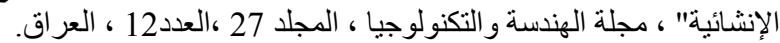

[10] Bageis, A. and Fortune. C. 2009: Factors Affecting the Bid/No bid Decision in the Saudi Arabian Construction Contractors, Construct Manage Econom 2009;27:53-71.

[11] Alfouzan, A. 2013: Analyzing the factors that lead to housing and construction cost escalation: A case study focused on Riyadh, Saudia Arabia. M.Sc. thesis, Western Kentucky University, Bowling Green, Kentucky.

[12] Zujo, V., CarPusic, D. and Brkan-Vejzovic, A. 2010: Contracted Price Overrun as Contracted Construction Time Overrun Function, Technical Gazette, Vol.17 No.1.

[13] Ameh, O., Soyingbe, A., and Odusami, K. 2010: Significant Factors Causing Cost Overruns in Telecommunication Projects in Nigeria, Journal of Construction in developing countries, 15(2):49-67.

[14] Singh, R. 2011: Determinants of Cost overrun in Public Procurement of Infrastructure: Roads and Railways in the India Policy Forum, Vol 7, pp 97-158, Working Paper Version.

[15]Shanmuganathan, N. and Baskar, G. 2015: Ranking of delay factors causes time and cost overruns in construction projects in Tamil Nadu, International Journal of Applied Engineering Research; Vol 10, no24.

[16] Gajewska, E. and Ropel, M. 2011: Risk Management Practices in a Construction Project, M.Sc. thesis, Chalmers University of technology, Goteborg, Sweden.

[17] Memon, A.; Abdul Rahman, I. and Abdul Azis, A. 2011: Preliminary Study on Causative Factors Leading to Construction Cost Overrun, International Journal of Sustainable Construction Engineering \& Technology Vol 2, Issue 1.

[18] Toh, T.; kherune, N.; Godwin, U. and Connie, T. 2012: Critical Cost Factors of Building Construction Projects in Malaysia, International Conference on Asia
Pacific Business Innovation and Technology Management. Procedia - Social and Behavioral Sciences $57,360-367$.

[19] Mahamid, I. and Bruland, A. 2011: Cost overrun Causes in Road Construction Projects: Consultants' Perspective, 2nd International Conference on Construction and Project Management, IPEDR vol.15, IACSIT Press, Singapore.

[20]Banaitiene, N. and Banaitis, A. 2012: Risk management - current issues and challenges, chapter 19, InTech, Croatia.

[21] Apolot, R., Alinaitwe, H. \& Tindiwensi, D. 2012: An Investigation into the Causes of Delay and Cost Overrun in Uganda "s Public Sector Construction Projects", Second International Conference on Advances in Engineering and Technology.

[22] Doloi, H. 2013: Cost overruns and Failure in Project Management: Understanding the Roles of Key Stakeholders in Construction Projects, J. Constr. Eng.Manage. 139 (3), 267-279.

[23]Siemiatycki, M. 2015: IMFG Perspectives (Cost Overruns on Infrastructure Projects: Patterns, Causes, and Cures), no.11, University of Toronto, Canada.

[24] Shaqour, E. 2014: An approach to Control Cost overrun in Construction Projects of Egypt, Doctor Dissertation in Architecture Engineering, faculty of Engineering, Cairo University, Egypt.

[25] Khodeir, L. and Hamdy, A. 2015: "Identifying the Latest Risk Probabilities Affecting Construction Projects in Egypt according to Political and Economic Variables", HBRC Journal; Vol 11, Issue 1, P129:135. 